\title{
Advancing community-based tourism approaches for the sustainable development of destinations
}

\author{
By Mtapuri, O. ${ }^{1}$, Camilleri, M.A. ${ }^{23}$ Dlużewska, A. ${ }^{4}$
}

Suggested Citation: Mtapuri, O., Camilleri, M.A. \& Dłużewska, A. (2021). Advancing community-based tourism approaches for the sustainable development of destinations. Sustainable Development, https://onlinelibrary.wiley.com/doi/10.1002/sd.2257

This is a prepublication version.

\begin{abstract}
This contribution suggests that community-based tourism (CBT) can create commercial and social value to destinations, local businesses as well as to residents. At the same time, it clarifies that CBT offers rich, immersive cultural experiences that can enhance the tourists' experiences when visiting different communities. It posits that sustainable CBT approaches can improve the local economic development (LED) of communities by reducing economic leakages from the tourism industry. It explains that there is scope for destination managers and tourism businesses to engage in sustainable tourism practices and to utilize local resources, in a strategic manner, in order to maximize linkages in their economy. In conclusion, this paper puts forward a theoretical model that clearly illustrates the business case to implement sustainable CBT strategies. It also implies that these strategies can ultimately result in opportunities for economic growth of tourism businesses and may increase the competitiveness of destinations, whilst safeguarding the environment and addressing their carrying capacities.
\end{abstract}

Keywords: Community-based tourism; sustainable tourism; carrying capacity, supply, Corporate Social Responsibility; CSR.

\footnotetext{
1 School of Built Environment and Development Studies, University of KwaZulu Natal, South Africa, Email: mtapurio@ukzn.ac.za

2 Department of Corporate Communication, Faculty of Media and Knowledge Sciences, University of Malta, Malta. Email: mark.a.camilleri@um.edu.mt

${ }^{3}$ The Business School, University of Edinburgh, Edinburgh, Scotland, U.K.

${ }^{4}$ Anna Dłużewska (Dłużewska, A.), Department of Earth Sciences and Spatial Management, Uniwersytet Marii Curie Skłodowskiej, Lublin, Poland. Email: anna.dluzewska@poczta.umcs.lublin.pl
} 


\section{Introduction}

Tourism is an important pillar for the economy of many countries and localities around the world. However, at times, social, economic, environmental and cultural aspects can have a negative effect on destinations, resulting in substantial losses to the tourism sector and to its associated beneficiaries (Caday-Fillone \& Villanueva, 2019:4, Dłużewska 2018; Dłużewska \& Giampiccoli, 2020). Therefore, tourism businesses ought to continuously monitor the latest developments in their marketing environment. The positive influences of tourism and its multiplier effects do not happen automatically. The tourism industry relies on the development of other sectors in the local economy (Terzioglu \& Gokovali, 2016:717) and on the socio-economic conditions of other countries (Wiranatha, Antara \& Suryawardani, 2017:2). In some cases, particularly in developing countries, the tourism receipts may have no impact on the local economies and their growth prospects, if the revenue that is generated by tourism will be utilized to invest in improving the destinations' infrastructure and resources (Chirenje et al., 2013:9; see also Garrigós Simón, Galdón Salvador \& Gil-Pechuán, 2015:725). Notwithstanding, various countries must import goods and services to be in a position to offer their tourism products. As a result, many destinations may experience certain "economic leakages" in their gross tourism earnings (UNWTO, 2002).

Financial leakages may occur when a disproportionately low percentage of tourism revenues remains in the local market, thereby reducing the positive effects of tourism. Leakages can vary from $10 \%$ to $70 \%$ and up to $80 \%$ in places such as the Caribbean (Wiranatha, Antara \& Suryawardani, 2017:3). In contrast, "linkages" are conspicuous with the utilization of local goods and services. Economic linkages may lead to the creation of more jobs and opportunities for small and medium sized businesses (UNWTO, 2002:11). Tourism and hospitality enterprises necessitate different resources to operate their businesses. Very often, the products they need, cannot always be acquired from local businesses. Hence, they may have to import them to provide an adequate level of service to their consumers. Their expenses can cause significant leakages from the economy (Terzioglu \& Gokovali, 2016:717). Food imports represent a very significant leakage in the hotel sector, such as in Jamaica, where foreign exchange leakages relating to food purchases were estimated to hover around 50\% (Terzioglu \& Gokovali, 2016:717). 
The hotel industry's costs and expenses resulting from such leakages can lower the multiplier effects of tourism. Consequentially, some destinations may experience reduced linkages in their economy as they lack appropriate resources (Cheer, Pratt, Tolkach, Bailey, Taumoepeau \& Movono, 2018:450). The leakages in the tourism sector are usually prevalent in poorer economies, in those that are not in a position to respond to the ongoing demands of the sector (Chirenje et al., 2013:9). On the other hand, linkages represent the procurement of goods and services that are derived from other sub-sectors from the local economy (Spinrad, Seward \& Bélisle, 1982:22). The practical strategy for many countries that are aspiring to build their tourism destination, is to invest in fostering the right environment for linkages with local businesses (suppliers), in order to enhance their economic development and competitiveness (UNWTO, 2002:11). For example, the tourism-agriculture linkages, among others, can prevent economic leakages and increase food security (Thomas, Moore \& Edwards, 2018:147).

National government together with the private sector could allocate resources toward LED and CBT initiatives to trigger business activity in tourist destinations, that will ultimately create jobs and economic growth (Nel \& Binns, 2002; Sara, 1993:139). LED is a territorial-based, sustainable tourism approach. It focuses on creating social and economic opportunities for local communities and enterprises (Rodríguez-Pose \& Tijmstra, 2010: 38). However, the growth of tourism destinations may be limited by their respective carrying capacities (Sabokkhiz et al., 2016:105).

The concept of carrying capacity combines "social, economic and environmental dimensions" and includes physical carrying capacity, social carrying capacity and economic carrying capacity (Pasko, 2016:166). Marsiglio (2017) suggested that carrying capacity refers to the maximum number of tourists that can visit a destination during a specified period. The author implied that the benefits from tourism must outweigh its costs to be sustainable. Arguably, tourism can have a detrimental effect on the natural environment as tourists utilize the destinations' infrastructures, including transportation facilities and utilities like water and electricity. They also consume resources and generate waste. Hence, the tourists as well as the tourism and hospitality businesses have a responsibility to bear for their externalities to the environment. This argumentation is consistent with the corporate social responsibility (CSR) discourse (Camilleri, 2019). 
CSR can be defined as "the businesses' responsibility toward society and the environment" (Farmaki, 2019; Camilleri, 2012). Businesses, including tourism companies may be intrigued to engage in CSR if their responsible behaviors add value to society as well as to their company's financial results (Camilleri, 2020). Therefore, strategic CSR practices can increase linkages (whilst decreasing leakages) in the economy. They can also address issues relating to carrying capacity (Kennel, 2016; Marsilio, 2017).

Before the outbreak of COVID-19, a surge in tourism has exceeded the environmental or social carrying capacity of many destinations (OECD, 2020:96). In this light, this contribution proposes a new approach to sustainable CBT, that relies on strategic CSR practices, and on the destinations' allocation of resources to enhance their carrying capacity and increase economic linkages. This research suggests that tourism businesses can engage in responsible initiatives that are meant to facilitate linkages and reduce leakages from dispersed supply chains. It is on this basis that this article advances a different approach to carrying capacity (Farrington et al., 2017; de Grosbois, 2012; Idahosa, 2019; Lund-Durlacher, 2015; Kasim, 2006; Coles, Fenclova \& Dinan, 2013) that is linked to the concept of CBT and strategic CSR perspectives. In sum, it suggests that CBT can be reconceived to increase linkages and LED. To the best of our knowledge there are no other contributions that have integrated CBT with strategic CSR behaviors that can add value to the economy and to local communities. Therefore, this research addresses this gap in academic literature.

The following section presents a critical review of the relevant literature relating to the leakages/linkages in the tourism sector. It discusses about their effect on CBT and on the destinations' carrying capacity. Afterwards, the researchers put forward a conceptual model that clarifies that a sustainable CBT approach can address issues relating to the carrying capacity and to economic development of tourist destinations. Finally, they outline their implications and identify future research directions to academia.

\section{Background - leakages and linkages in tourism}

LED fits well with "community-based development initiatives" (Nel, 2001: 1005) and with tourism development that has a territorial focus as it is intended to improve the sustainability of destinations (Rodríguez-Pose \& Tijmstra, 2010: 35). In the global context, 
there are many countries that have already implemented different measures that led to significant improvement for their LED (Rodríguez-Pose \& Tijmstra, 2010: 35; Nel, 2001). However, at times, policy makers were not always engaging with the private sector. As a result, they were not always successful in enhancing the economic linkages with local business communities. Leakages can have negative effects on the hotel industry, to the extent that they impede their economic growth and sustainability (Alzboun, Khawaldah, Backman \& Moore, 2016:18).

Common economic leakages may include foreign-controlled multinational firms, the importation of goods, and the creation of jobs to non-residents (Terzioglu, \& Gokovali, 2016:716). Leakages from the economy could involve different industries like building and construction, financial services, hospitality and/or the manufacturing sectors when they recruit foreign nationals (Wiranatha, Antara \& Suryawardani, 2017:3). The size of the economic leakages depends on size of the employer. For example, in the hospitality industry, the larger hotels may usually import executives from other countries, whereas the smaller hotels tend to employ local employees.

Moreover, foreign owned, luxury hotels will usually import their requirements, as opposed to locally owned hotels that may procure their food and beverage products from local suppliers. Terzioglu and Gokovali (2016:718) reported that Indonesian non-star accommodation establishments sourced their food requirements from local farmers. Other research confirmed that the larger, high end, foreign-owned accommodation establishments are creating greater leakages than the smaller, lower end, locally-owned hospitality enterprises (Hampton, Jeyacheya \& Long, 2018; Pratt, Suntikul \& Dorji, 2018).

The lack of linkages between tourism businesses and their suppliers, may result in increases in imports particularly in cases when local products including food, fruit and vegetables are not available (Terzioglu \& Gokovali, 2016:717). Certain food products may be scarce in the domestic market because of three main reasons: firstly, the local geographical context of the host destination, in terms of climate and terrain, can have an effect on the quality and quantity of food items that can be procured by tourism businesses. For example, bananas cannot be harvested in Greenland, and rhubarb cannot be grown in Mediterranean areas, unless they are kept in controlled conditions; secondly, specific human competences/expertise may be required for the production of certain goods and/or for the delivery of hospitality services that are linked to the tourism market (e.g. certain 
destinations are sought by tourists for culinary, wine or oleo tourism products); and thirdly, specific products may require a huge capital investment outlay, and small businesses and local entrepreneurs may lack access to finance. These issues can have an effect on certain destinations' economic growth and competitiveness.

In addition to the above factors, the size of land that may be developed for tourism, is another important factor for destination marketers. Small countries like the Maldives, are restricted by their land size to grow their agricultural products. Small islands may be limited in their capacities to produce large amounts of fruit and vegetables to cater for local residents and to their tourists' needs. Of course, the governments are encouraged to support businesses to source food requirements, locally. This way, they will be in a position to procure fresher foods and beverages at convenient prices.

Policy makers can assist the informal sector by educating entrepreneurs about the benefits of sustainable tourism practices and could encourage them to engage with stakeholders. The concept of sustainable tourism also underlines the importance of facilitating community involvement in tourism as local enterprises and even individual citizens can contribute to their destination's economic development (Lasso \& Dahles, 2018:473). Alzboun et al.'s (2016) study on the effect of sustainability practices on financial leakages indicated that community participation in the hotel industry is vital to curb leakages from the local economy. As such, community involvement is increasingly being regarded as essential for the effectiveness of sustainable tourism planning and destination management (Eshliki \& Kaboudi, 2012:334).

The sustainability of destinations has also been linked to other issues. For instance, in the context of island states, it is important to ensure that the do not exceed their carrying capacity. A high influx of tourists beyond the destinations' capacities can have detrimental effects on local communities and their natural environments, as they have limited resources (Sánchez-Cañizares, Castillo-Canalejo \& Cabeza-Ramírez, 2018:2). Their long-term sustainability can be hampered by an inequitable distribution of resources, privatisation of the commons and by the accumulation of wealth in specific social groups (Boluk, Cavaliere \& Higgins-Desbiolles, 2019). These issues, that are clearly accentuated in foreign-owned, high-end and larger establishments, may result in economic leakages.

Many tourists are shifting from large hotel chains to smaller accommodation establishments. They do so as they want to engage in closer relationships with local 
communities and with small tourism enterprises (Lindström, 2020). This engagement is usually mutually beneficial to both parties (Chilufya, Hughes \& Scheyvens, 2019).

\section{Community-based tourism}

Community-based tourism (CBT) is a strategy that encourages the social organization of the local communities (López-Guzmán, Borges \& Cerezo, 2011). CBT relies on the inclusion and active engagement of local tourism stakeholders. Local stakeholders are expected to share their resources and to work together towards common goals (Strydom, Mangope \& Henama, 2017). CBT approaches involve members from the local community in the decision making relating to tourism development. The "ownership, management, operation and supervision" of the tourism businesses belong to local entrepreneurs who are also community members (Arintoko et al., 2020:399; Wijaya, Hartati \& Sumadi, 2020:2; Karacaoğlu \& Birdir, 2017:53; Strydom, Mangope \& Henama, 2017:1). While being similar to sustainable tourism, CBT is unique in prioritising the locals' empowerment in defining their own future (Tasci, Semrad \& Yilmaz, 2013:9). Community-based tourism is also participatory in nature. It transcends confidence and knowledge building as communities are empowered to chart their trajectory for tourism development (Tasci, Semrad \& Yilmaz, 2013:15; Mearns, 2012:72).

There is a wide plethora of definitions in academia that describe the characteristics of CBT. Very often, this term is linked to a community including its natural resources and its local economy (and systems). CBT specifies the objectives that can ultimately improve the quality of life of local residents (especially to those who belong to vulnerable groups in society). CBT implies that communities can control and manage their local resources for their own benefit (Karacaoğlu \& Birdir, 2017:59). The objectives of CBT include the conservation of local communities and of their natural and cultural resources in order to contribute to their socio-economic development. López-Guzmán, Borges and Cerezo (2011) contended that CBT can truly enhance the quality of the tourist experiences when tourism businesses are run by local entrepreneurs. Therefore, CBT is about improving the local economy for the benefit of the people. At the same time, the CBT notion is also focused on the preservation of the natural environment (Lee \& Jan, 2019:370). Many researchers contended that $\mathrm{CBT}$ raises awareness about the businesses' responsibility to 
engage in responsible tourism practices to safeguard the natural, social and cultural environments (Wijaya, Hartati \& Sumadi, 2020; Jugmohan, Spencer \& Steyn, 2016).

Various researchers argued that tourism is dependent on the very same resources it consumes, therefore tourism marketers should devote special attention to preserve them. For instance, Mason (2003:31) noted that "natural, man-made and cultural resources that tourism relies upon are liable to be overconsumed". Recently, (Dodds, 2020) maintained that tourism needs to protect the very resources upon which it depends. Local communities ought to their safeguard their urban and natural environment, culture and traditions, et cetera. It is in their interest to involve themselves in the decisions about their destination's tourism development (Karacaoğlu \& Birdir, 2017:53). The duty of the community members is to conserve the resources in their neighborhood (Martini, 2020:93). They are responsible to maintain and to care for their resources, for their own benefit, and for those who will come after them. This implies that communities should be proud of the legacy that they will leave behind to future generations.

One of the enablers for sustainable CBT development is to limit visitors according to their carrying capacity (Asker, et al., 2010:4). Okazaki (2008:511) is of the view that a community participation approach has the potential to reduce the negative impacts on the communities as they are in the position to limit their capacity to acceptable levels. In plain words, a sustainable CBT approach entails attracting tourist to a destination, before reaching its threshold (i.e. its carrying capacity of a locality), without posing detrimental and/or irreversible damages to both the community, the environment and local cultures.

On the contrary, when tourism development is dependent on external entities like international hotel chains, they may focus on their bottom lines rather than upholding the interests of the local communities (Tasci, Semrad \& Yilmaz, 2013). Very often, these pursue mass tourism (and over tourism) strategies that are aimed at increasing their profits. Therefore, a CBT approach is usually considered to be more sustainable tourist arrivals are controlled (Prasiasa, et al., 2020:153). It is also intended to reduce the hegemonic influences of international tour operators (Chaudhary \& Lama, 2014:241). Moreover, it ensures that communities as well as of local enterprises are actively involved in the development of their destination's tourism product (Camilleri, 2018; Giampiccoli \& Saayman, 2018). 
CBT can alleviate poverty in different communities. It could support the disadvantaged members in the community, including small businesses and individual entrepreneurs, with the aim of reducing leakages from the local economy. The development CBT relies on the communities' control, ownership and management of local resources, services and facilities such as accommodation establishments, tourism agencies, and restaurants; thereby encouraging linkages between different sectors in the local economy.

The contribution of CBT to the economy goes far beyond the tourism sector. Sustainable CBT approaches can improve the socio-economic development of small communities and could facilitate the interaction between local communities and their visitors. Furthermore, CBT raises awareness on environmental protection and promotes the responsible utilization of resources. Hence, CBT by its nature is intended to reduce the leakages from the local economy and to address contingent issues relating to their carrying capacity (Butler, 2020; Caday-Fillone \& Villanueva, 2019).

\section{Carrying capacity}

The World Tourism Organization defines carrying capacity as "the maximum number of people that can visit a tourist destination at the same time, without causing destruction of the physical, economic, sociocultural environment and an unacceptable decrease in the quality of visitors' satisfaction" (UNWTO 1981: 4). Therefore, this concept is related to those strategies, indicators and targets that are intended to limit the volumes of visitors, in the interest of the environment and of the host communities. Carrying capacity has evolved from a purely qualitative and normative concept to a more quantitative topic (Caday-Fillone \& Villanueva, 2019:6). Other concepts that are 'similar' to carrying capacity include: Limits of Acceptable Change (LAC), Visitor Experience and Resource Protection (VERP), Visitor Impact Management (VIM), among others (Kennell, 2016:133). These measures illustrate the importance of sustainability in the context of inbound tourism.

Carrying capacity and sustainability are interrelated and should both be considered together as "useful concepts and frameworks that are meant to analyze the impacts and limits of tourism development" (Saarinen, 2006:1125). However, there are many definitions for both constructs, because of different opinions on culture, nature and their use as resources (Saarinen, 2006:1126). Sustainability and carrying capacity both "refer to 
the scale of tourism activity that can occur in a spatial unit without doing any serious harm to the natural, economic, and sociocultural elements at destinations" (Saarinen, 2006:1126). However, while sustainability is considered as a global concept, carrying capacity focuses on the physical, economic, perceptual, social, ecological, and political contexts of a specific location (Saarinen, 2006; Massiani \& Santoro, 2012:143; Kennell, 2016:133).

For instance, socio-economic carrying capacity "may be defined as the total number of visitors that can be allowed without hindering the other functions that the city performs" (Massiani \& Santoro, 2012:143) or alternatively the economic carrying capacity is related to the tourists' maximum use of the destination's resources, before leading to an unacceptable level of economic dependency on them (Kennel, 2016). UNWTO (1983) clarified that an optimum carrying capacity can be reached when the volume of inbound tourism provides economic benefits to the local community. Hence, there is scope for tourist destinations to establish their capacity levels in order to yield maximum economic benefits with a minimal disruption to local cultures and societal well-being. In this context, WTO (1983) commends that destination marketers ought to investigate how they can use their resources, competences and capabilities in a strategic and sustainable manner (WTO, 1983:19).

\section{Corporate social responsibility and sustainable tourism}

The concepts of environmental sustainability, CSR, and responsible tourism are interlinked and embedded within each other (Idahosa, 2019). Idahosa (2019: 961) contended that responsible tourism is related to CSR in the tourism sector. It also borrows a lot from the sustainable tourism movement which arose following the increased awareness for sustainable development (Camilleri, 2014; Brundtland, 1989).

The concept of CSR is usually associated with the private sector's voluntary actions that are intended to address environmental, social, cultural and economic issues, to improve relationships with stakeholders (Baniya, Thapa \& Kim, 2019:3; see also Coles, Fenclova \& Dinan, 2013:122; Lund-Durlacher, 2015). "CSR is typically integrated into the organizations' mission and vision to cover financial, environmental and social aspects" (Smith \& Ong, 2015: 488). Arguably, there is more to CSR that doing good. Several theoretical underpinnings reported that there is a business case for CSR (Camilleri, 2017). 
CSR practices in hotels can be driven by a number of factors including operational efficiencies and cost savings, societal pressures, profit maximization and brand positioning (Farmaki, 2019:2297; Camilleri, 2014).

The hotel sector can implement CSR initiatives to promote the 'triple bottom line' approach where socio-economic and environmental issues are given equal weight in their strategies (Farmaki, 2019). This way, they can enhance their firm's image and boost their reputation with stakeholders. At times, stakeholders perceive that CSR behaviors are triggered by opportunistic motives. They may believe that responsible initiatives are prompted by the businesses' self-interest rather than by their altruistic motives to pursue the common good (Randle, Kemperman \& Dolnicar, 2019:66). However, many studies have proved that businesses can do well by doing good. CSR can add value to the businesses themselves (Camilleri, 2017).

In this light, this contribution suggests that tourism firms can address economic, environmental, cultural and social dimensions in the communities where they operate their business, to be successful. These dimensions are mutually reinforcing, as illustrated in Figure 1. 
Figure 1. The links between CSR, carrying capacity and sustainable tourism framework

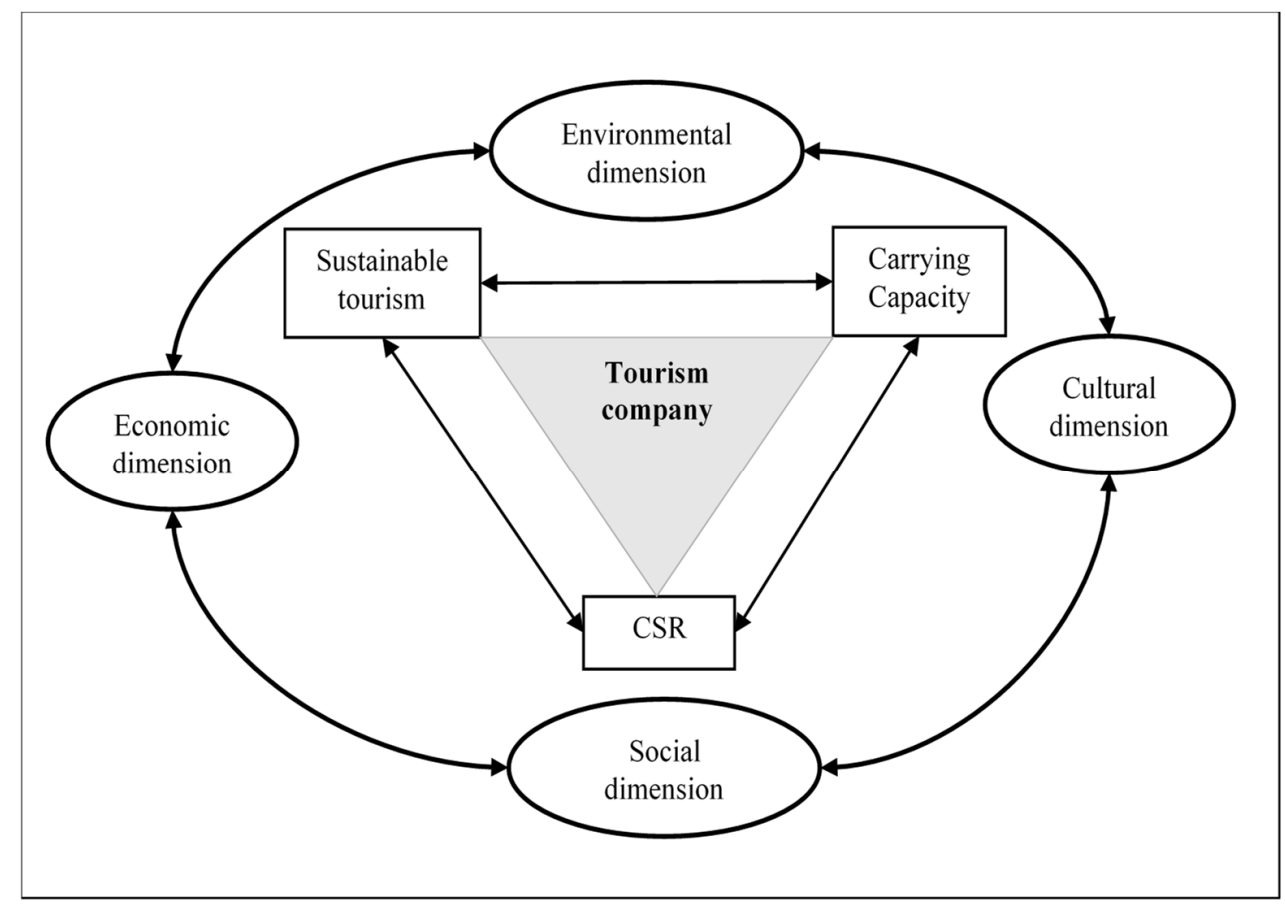

Although CSR is increasingly being conceptualized as an important element for sustainable tourism (Martin-Rios, 2020; Moral Moral, Fernández Alles \& Sánchez Franco, 2018), very often research reported that owners of accommodation establishments are not providing appropriate working conditions to their employees (Harris \& Pressey, 2021). The tourism and hospitality industry sectors are major global forces for economic growth and competitiveness. Therefore, hotel businesses, in particular, ought to engage in responsible behaviors to improve their relationships with stakeholders, including employees (Camilleri, 2015). They can support the community through social responsible practices like sponsorships of cultural, music or sporting events, et cetera, where they operate their business. Moreover, they should adopt environmentally friendly practices to improve their operational efficiencies and cost savings, thereby creating competitive advantages (LundDurlacher, 2015:9). Businesses can invest in water and energy conservation. Alternatively, they can minimize their waste by reusing resources. For example, grey water can be utilized for irrigation purposes (Scheyvens, 2007:140).

There is scope for governments to raise awareness on the business case for CSR. Governments must step up with their commitment to the challenge of guaranteeing the 
environmental and economic sustainability of the tourism industry (Trong Tuan, 2011; Dodds et al., 2009). They can incentivize tourism businesses by providing tax credits to trigger CSR and environmentally-responsible behaviors (Baniya, Thapa \& Kim, 2019:9). Hence, companies could implement laudable practices that will enhance local economic and social development. At the same, they may be in a better position to invest in technologies to reduce their environmental impacts (Giampiccoli \& Mtapuri, 2020). Ultimately, it is in the businesses' self-interest to engage in CSR and environmentally responsible practices. Various studies confirmed that corporate responsible behaviors can lead to an increased financial performance (Tien, Anh \& Ngoc, 2020; Yim, Bae, Lim \& Kwon, 2019).

\section{Carrying capacity and sustainable tourism}

A United Nations Commission on Sustainable Development document (UNCSD NGO Steering Committee, 1999:4) shed light on the hidden costs and economic leakages that are conspicuous in the tourism industry. Many countries, particularly those hailing from the developing economies are losing a significant amount of their revenues due to economic leakages to foreign-owned businesses. Botswana represents an example of this phenomenon. This Southern African country is leaking tourism revenues because of its inability to foster economic linkages by supporting local businesses (Mbaiwa, 2005:164). While the sector is reportedly 'a huge driver of pro-poor tourism', Botswanan firms are still import physical resources like building materials from other countries as well as human resources, including employees and executives from other countries (Manwa \& Manwa, 2014:5707). Previous research suggested that high economic leakages can jeopardise the sustainability of the tourism industry (Garrigós Simón, Galdón Salvador \& Gil-Pechuán, 2015:725). The level of leakages in a destination is associated with its capacity to supply goods and services to what the market demands (Garrigós Simón, Galdón Salvador \& GilPechuán, 2015:725).

An increase in capacity can be achieved if the sector attracts an optimum number of inbound tourists throughout the year, including during the low season and in the shoulder months. Very often, destinations experience a surge in tourism during their peak season. Such an imbalance is not sustainable to the host destination. Therefore, the carrying capacity of destinations ought to be associated with the resources at their disposal. Specific 
geographical areas and certain cities cannot sustain a large influx of tourists, although they may experience demand for their attractions. Tourism marketers should bear in mind that their destination cannot deliver appropriate services to their visitors if they exceed their carrying capacity.

In other words, a sustainable carrying capacity model involves identifying a specified number of visitors that can be supported by a destination's infrastructure. The feasibility of such a sustainability model would necessitate appropriate planning, organization, leadership and control of the destination's resources. At the micro level, tourism businesses are also expected to follow a similar carrying capacity approach. For example, hotels have to host a sustainable number of guests according to capacity. The hotel occupancy is constrained by its capacity levels.

Hotel accommodation establishments can use revenue management systems to better understand, anticipate, and react to market demand. This way can maximize their revenues. These systems can optimize their fixed, perishable inventory, and time-variable supply, through dynamic prices (Camilleri, 2018). Hospitality businesses can raise their prices to reduce demand during certain times of the year (particularly during high seasons). Their marketing communications could be directed at quality tourists who are willing to pay more for their services. Hence, fewer affluent tourists are more sustainable to the destination and to local businesses, than masses of price sensitive consumers. They will also result in lower detrimental effects to the natural environment as they would demand less resources from destinations and their communities.

From a community-based perspective, limiting tourism figures can improve the destinations' sustainability, whilst limiting the impacts on the natural environment (Saarinen, 2006:1129). Figure 2 illustrates a model that clarifies that mass tourism service providers, such as foreign owned properties including international hotel chains are usually associated with economic leakages (Garrigós et al., 2015). Whereas a sustainable tourism product which is based on locally-owned, smaller businesses, are usually aligned to economic linkages. Destinations can use CBT approaches to increase linkages by attracting high yield, affluent tourists to locally-owned companies (Butler, 2020; Prasiasa, et al., 2020). The tourism businesses ought to improve the quality of their services to appeal to high-end segments. 


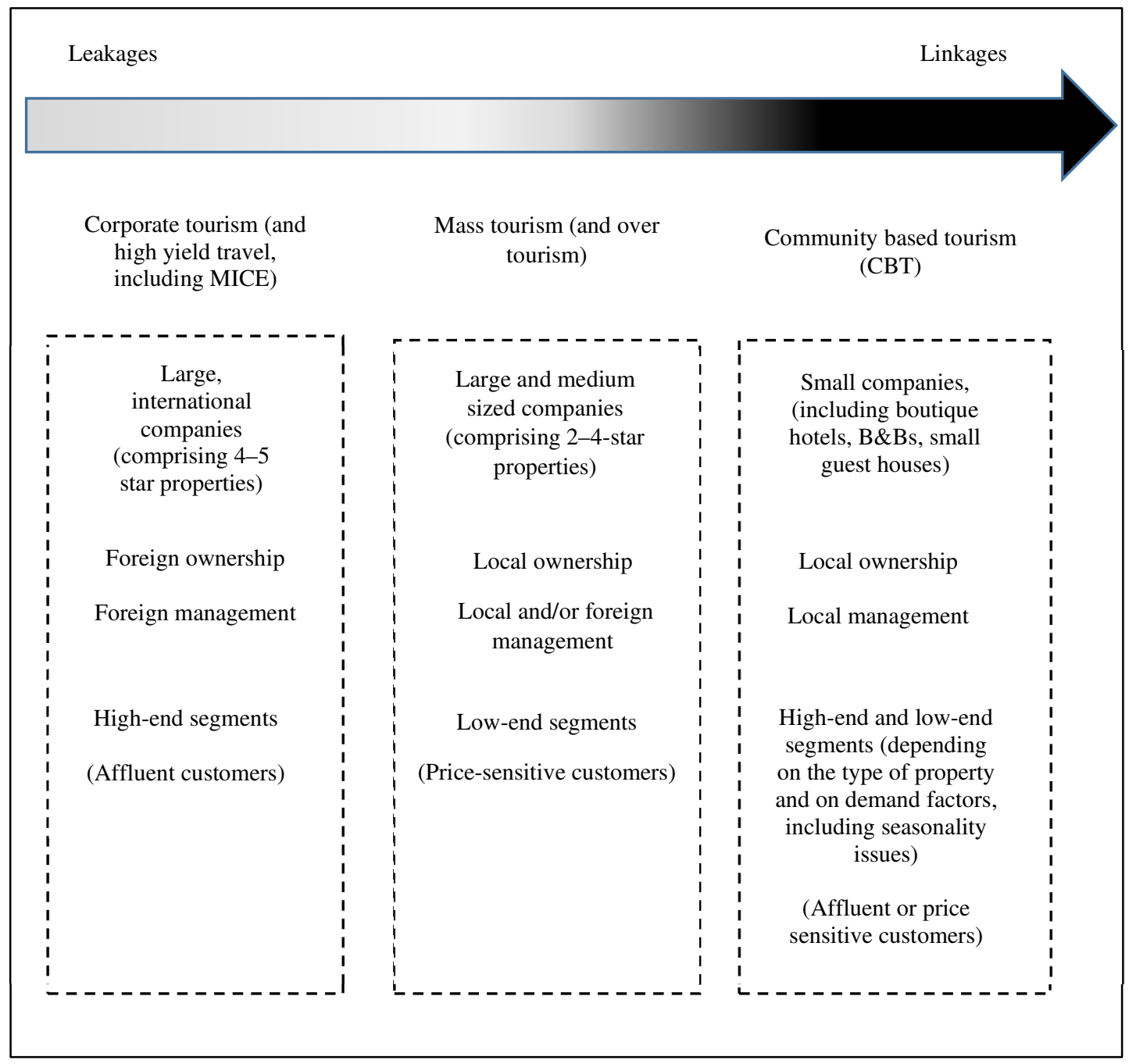

To be successful, the proponents of CBT ought to ensure that they retain its specific principles and characteristics. Thus, CBT practitioners could differentiate themselves from other business models by offering authentic, local experiences to their guests. CBT can establish itself as a niche tourism product that appeals to lucrative market segments. Therefore, CBT service providers are expected to deliver on their promises. They have to meet and exceed their customers' expectations without lowering their standards of service.

CBT operators rely on their community's local resources including environment/natural resources, heritage, culture as well as on knowledgeable human resources. Their employees should possess customer service skills, and ought to be trained about their local tourism products. Local businesses may usually engage native employees 
to improve their consumers' experiences with their CBT product. However, there may be instances where CBT operators may not find local employees in the labor market. In this case, they have to train their imported employees about local cultures and traditions in order to continue delivering authentic CBT experiences.

Figure 3 presents a model for sustainable CBT that relies on the destinations' effective management of their carrying capacities. An ongoing evaluation of the destinations' infrastructures as well as on their human and natural resources, particularly during their high season, is required to ensure that they do not exceed their specific carrying capacities. While each specific context will have its own specific performance indicators, this contribution suggests that destination marketers ought to consider the following issues:

- The participation of local businesses and individual in CBT.

- Local procurement of products (for accommodation establishments, hotels, restaurants, and to other tourism businesses).

It is in the interest of CBT operators to think locally and act globally (Hofstede, 1998). They should consider sourcing their requirements from their local communities, where possible. Hence, tourism planners could utilize local resources to reduce leakages from their economy. Governments can encourage tourism businesses to support local enterprises, for example, by purchasing local products, by supporting the local community through CSR and environmentally responsible practices. They can raise awareness on corporate responsible behaviors and on sustainable tourism initiatives. They may also incentivize businesses through financial instruments to pursue laudable activities. They can also provide support to tourism businesses, including small hotels and B\&Bs to upgrade their services to attract lucrative tourists in their communities. Of course, governments are expected to maintain their destinations' infrastructure and to offer suitable amenities to their visitors.

These strategies are meant to foster an environment that promotes sustainable CBT approaches that are intended to increase economic linkages, whilst improving societal and the environmental outcomes in local communities. Figure 3 clarifies how tourism businesses can optimize the utilization of local resources through sustainable CBT 
strategies in order to improve their destination's carrying capacity whilst reducing leakages from their economy.

Figure 3. A sustainable model for community-based tourism

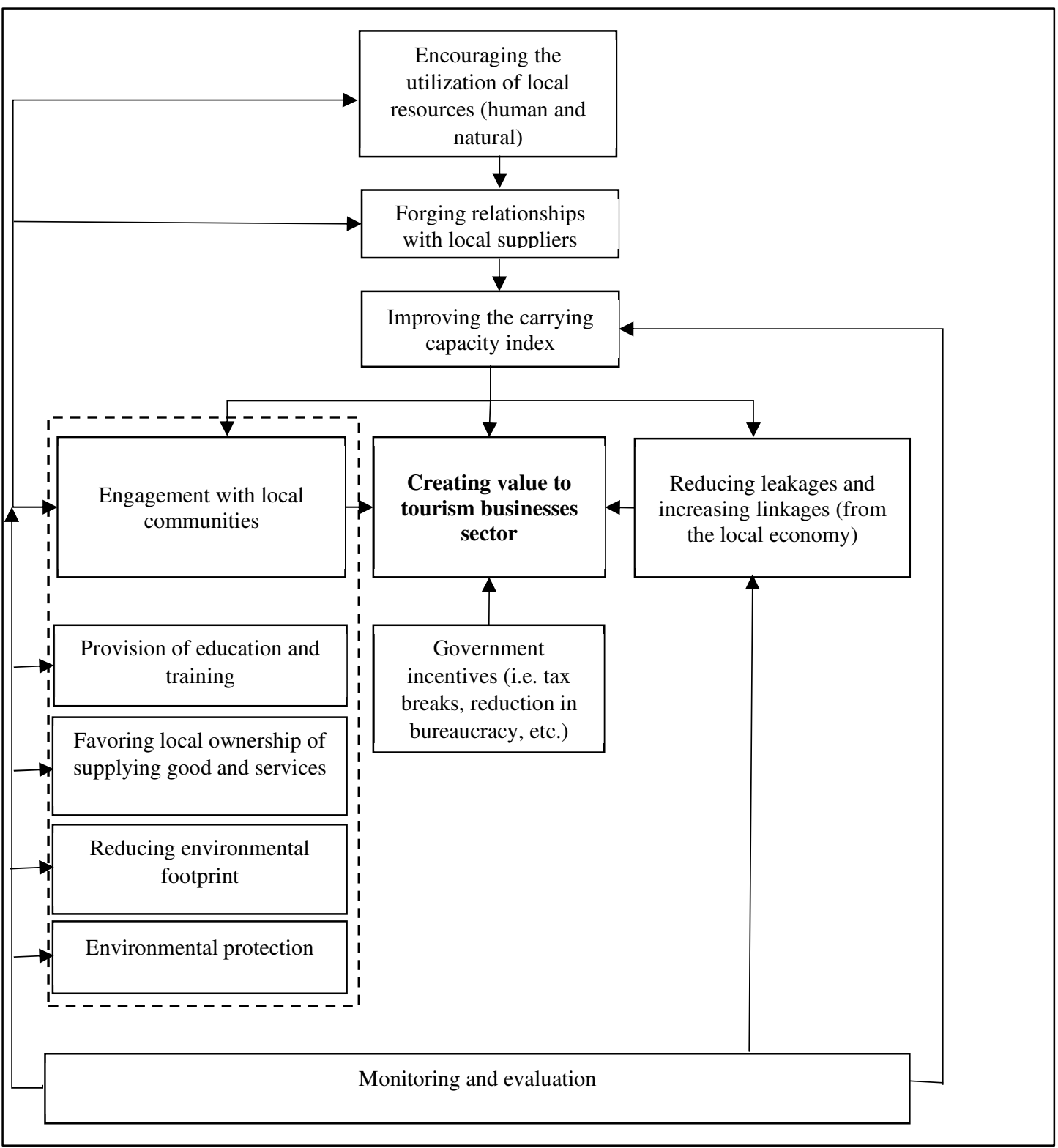

\section{Conclusions and implications}

The effectiveness of this proposed model for sustainable community-based tourism relies on a regular evaluation of the marketing environment. Tourism practitioners are 
expected to examine and re-examine their CBT strategies to ensure that they are still creating value to their business, to the local community and to the environment at large.

Sustainable CBT approaches can support the local economic development of destinations, however leakages can jeopardize the destinations' competitiveness and growth prospects. While the degree and types of leakages may vary, according to specific characteristics of certain countries, it can be argued that the proper utilization of local resources can improve the national economies and the quality of life of different communities, including those from emerging economies.

The type of tourism planning and development that is adopted by certain destinations is another factor that can have an effect on their economic leakages or linkages. Based on the above, this contribution puts forward a theoretical model that is intended to address the limitations of the carrying capacities of various destinations. In sum, it suggests that sustainable CBT approaches that rely on the optimal utilization of local resources (including human and natural) may result in economic growth as well as in positive outcomes to local communities and their natural environments. This model is aimed at rebalancing leakages with linkages in the economy, whilst responding to challenges relating to the supply chains of different tourism businesses.

Indeed, there is scope for destinations to maximize the use of resources at their disposal (both human and natural). In a similar vein, companies should avail themselves of local resources, competences and capabilities. It is also in their interest to engage in strategic CSR and sustainable tourism practices to support local stakeholders and to safeguard their natural environment.

A sustainable CBT model would require tourism businesses to forging relationships with different stakeholders including with the government and its policymakers, suppliers, creditors, employees and customers, among others. The advancement of CBT would also necessitate that destination marketers and hospitality businesses work together, in tandem to improve their tourism product. Local stakeholders are expected to safeguard their natural environment, culture and traditions for the benefit of their communities, and for their valued tourists and visitors who would probably appreciate authentic destinations that offer unique experiences to them. 


\section{References}

Alzboun, N., Khawaldah, H., Backman, K. \& Moore, D. (2016). The effect of sustainability practices on financial leakage in the hotel industry in Jordan. Journal of Hospitality and Tourism Management, 27, 18-26.

Arintoko, A., Ahmad, A.A., Gunawan, D.S. \& Supadi, S. (2020). Community-based tourism village development strategies: a case of Borobudur tourism village area, Indonesia. GeoJournal of Tourism and Geosites, 29(2), 398-413.

Asker, S., Boronyak, L., Carrard, N., \& Paddon M. (2010). Effective community based tourism: a best practice manual. APEC Tourism Working Group. Griffith University: Sustainable Tourism Cooperative Research Centre.

Baniya, R., Thapa, B. \& Kim, M-S. (2019). Corporate Social Responsibility among Travel and Tour Operators in Nepal. Sustainability, 11(2771): 1-13.

Boluk, K. A., Cavaliere, C. T. \& Higgins-Desbiolles, F. (2019) A critical framework for interrogating the United Nations Sustainable Development Goals 2030. Agenda in tourism, Journal of Sustainable Tourism, 27:7, 847-864.

Brundtland, G. H. (1987). Our common future: The Brundtland report. Retrieved April 10, 2009, from http://anped.org/index.php?part=176

Butler, R. W. (2020). Tourism carrying capacity research: a perspective article. Tourism Review, 75(1), 207-211.

Caday-Fillone, M. O. \& Villanueva, C. (2019). , "A Literature Review of Ecotourism Carrying Capacity Measurements: Initial Findings" (2019). Travel and Tourism Research Association: Advancing Tourism Research Globally. 12. https://scholarworks.umass.edu/ttra/2019/grad_colloquium/12

Camilleri, MA. (2014). Advancing the sustainable tourism agenda through strategic CSR perspectives. Tourism Planning \& Development, 2014, 11 (1), 42-56. https://www.tandfonline.com/doi/abs/10.1080/21568316.2013.839470

Camilleri, M. A. (2017). Corporate sustainability, social responsibility and environmental management. Cham, Switzerland: Springer International Publishing. Cham, Switzerland. https://link.springer.com/book/10.1007/978-3-319-46849-5

Camilleri, M.A. (2018). The tourism industry: An overview. Travel marketing, tourism economics and the airline product, 3-27. Springer, Cham, Switzerland. https://link.springer.com/chapter/10.1007\%2F978-3-319-49849-2_1

Camilleri, M. A. (2019). Measuring the corporate managers' attitudes towards ISO's social responsibility standard. Total Quality Management \& Business Excellence, 30(13-14), 1549-1561. https://www.tandfonline.com/doi/abs/10.1080/14783363.2017.1413344

Camilleri, M. A. (2020). Strategic corporate social responsibility in tourism and hospitality. Sustainable Development, 28: 504-506. https://onlinelibrary.wiley.com/doi/full/10.1002/sd.2059 
Cater, E. (1995). Environmental Contradictions in Sustainable Tourism. The Geographical Journal, 161(1), 21-28.

Chaudhary, M. \& Lama, R. (2014). Community Based Tourism Development in Sikkim of India - A Study of Darap and Pastanga Villages. Transnational Corporations Review, 6(3), 228-237.

Cheer, J. M., Pratt, S., Tolkach, D., Bailey, A., Taumoepeau, S. \& Movono, A. (2018). Tourism in Pacific island countries: A status quo round-up. Asia Pac Policy Stud, 5: $442-461$.

Chilufya, A., Hughes, E. \& Scheyvens, R. (2019) Tourists and community development: corporate social responsibility or tourist social responsibility?, Journal of Sustainable Tourism, 27:10, 1513-1529.

Chirenje, L. I., Chitotombe, J., Gukurume, S., Chazovachii, B. \& Chitongo, L. (2013). The Impact of Tourism Leakages on Local Economies: A Case Study of Nyanga District, Zimbabwe. Journal of Human Ecology, 42(1): 9-16.

Coles, T., Fenclova, E. \& Dinan, C. (2013). Tourism and corporate social responsibility: A critical review and research agenda. Tourism Management Perspectives, 6: 122141.

de Grosbois, D. (2012). Corporate social responsibility reporting by the global hotel industry: Commitment, initiatives and performance. International Journal of Hospitality Management 31: 896-905.

Del Baldo, M. (2018). Sustainability and CSR orientation through "Edutainment" in tourism. International Journal of Corporate Social Responsibility, 3(5): 1-14.

Dłużewska, A. M. (2018). Well-being versus sustainable development in tourism-The host

perspective. Sustainable Development. p. 1-11, DOI: 10.1002/sd.1903

Dłużewska, A., \& Giampiccoli, A. (2020). Enhancing island tourism's local benefits: A proposed community-based tourism-oriented general model. Sustainable Development. 1-12, DOI: 10.1002/sd.2141

Dodds, R. \& Joppe. M. (2009). The Demand for, and Participation in Corporate Social Responsibility and Sustainable Tourism - Implications for the Caribbean. ARA: Journal of Tourism Research, 2(1):1-11.

Dodds, R. (2020) Using a Participatory Integrated Watershed Management Approach for Tourism. Tourism Planning \& Development, 17:1, 1-16.

Eshliki S. A. \& Kaboudi, M. (2012). Community Perception of Tourism Impacts and Their Participation in Tourism Planning: A Case Study of Ramsar, Iran. Procedia - Social and Behavioral Sciences 36 (2012) 333 - 341. ASEAN Conference on EnvironmentBehaviour Studies, Savoy Homann Bidakara Bandung Hotel, Bandung, Indonesia, 15-17 June 2011.

Farmaki, A. (2019). Corporate social responsibility in hotels: a stakeholder approach. International Journal of Contemporary Hospitality Management, 31(6): 2297-2320. 
Farrington, T., Curran, R., Gori, K., O’Gorman, K. D. \& Queenan, C. J. (2017) "Corporate social responsibility: reviewed, rated, revised", International Journal of Contemporary Hospitality Management, Vol. 29 Issue: 1, 30-47.

Garrigós Simón, FJ.; Galdón Salvador, JL.; Gil Pechuán, I. (2015). The economic sustainability of tourism growth through leakage calculation. Tourism Economics. 21(4): 721-739.

Giampiccoli, A. \& Saayman, M. (2018). Community-based tourism development model and community participation. African Journal of Hospitality, Tourism and Leisure, 7(4), 1-27.

Giampiccoli, A. and Mtapuri, O. (2020). Introducing the Investment Redistributive Incentive Model (IRIM): A new redistribution perspective in tourism investment and beyond. African Journal of Hospitality, Tourism and Leisure 9(1/58): 1-16.

Hampton, M. P., Jeyacheya, J., \& Long, P. H. (2018). Can tourism promote inclusive growth? Supply chains, ownership and employment in Ha Long Bay, Vietnam. The Journal of Development Studies, 54(2), 359-376.

Harris, L. C., \& Pressey, A. (2021). Dirty work or working dirty? Deceiving cruise tourists. Annals of Tourism Research, 88,

Hofstede, G. (1998). Think locally, act globally: Cultural constraints in personnel management. In Management and international review (pp. 7-26). Gabler Verlag, Wiesbaden.

Idahosa, L. O. (2019). Understanding sustainability, Corporate Social Responsibility and responsible tourism in literature vs practice. GeoJournal of Tourism and Geosites, 26(3): 956-973.

Jugmohan, S., Spencer, J. P. \& Steyn, J. N. (2016). Local natural and cultural heritage assets and community based tourism: Challenges and opportunities. African Journal for Physical and Health Sciences, 22(1-2), 306-317.

Karacaoğlu \& Birdir, (2017). Success Factors of Community Based Tourism (CBT) Perceived by Local Peoples: The Case of \% 100 Misia Project. International Rural Tourism and Development Journal, 1 (2): 53-61.

Kennell, J., (2016). Carrying capacity. In Encyclopedia of Tourism (pp. 133-135). Springer International Publishing.

Lasso, A. \& Dahles, H. (2018) Are tourism livelihoods sustainable? Tourism development and economic transformation on Komodo Island, Indonesia. Asia Pacific Journal of Tourism Research, 23:5, 473-485.

Lee, T. H. \& Jan, F-H. (2019). Can community-based tourism contribute to sustainable development? Evidence from residents' perceptions of the sustainability. Tourism Management, 70, 368-380.

Lindström, K. N. (2020). Ambivalence in the evolution of a community-based tourism sharing concept: a public governance approach. Scandinavian Journal of Hospitality and Tourism, 20(3), 302-315. 
López-Guzmán, T., Borges, O. \& Cerezo, J. M. (2011). Community-based tourism and local socio-economic development: A case study in Cape Verde. African Journal of Business Management, 5(5), 1608-1617.

Lund-Durlacher, D. (2015): Corporate Social Responsibility and Tourism. In: Education for Sustainability in Tourism - A Handbook of Processes, Resources, and Strategies. Moscardo, P. \& Benckendorff, G. (eds.). Berlin: Springer, p. 59 - 73.

Manwa, H. \& Manwa, F. (2014). Poverty Alleviation through Pro-Poor Tourism: The Role of Botswana Forest Reserves. Sustainability, 6, 5697-5713

Marsiglio, S. (2017). On the carrying capacity and the optimal number of visitors in tourism destinations. Tourism Economics, 23(3), 632-646.

Martini, N. K. A. (2020). Community participation in Blangsinga tourism village development. International Research Journal of Management, IT and Social Sciences, 7(3), 91-97.

Martin-Rios, C. (2020). Sustainable Business Model: What Every Business Leader Should Ask Themselves. HospitalityNet, 20 March 2020. Retrieved 26 September 2020 from https://www.hospitalitynet.org/opinion/4097662.html

Mason, P. (2003). Tourism Impacts, Planning and Management. Oxford: ButterworthHeinemann

Massiani, J. \& Santoro, G. (2012). The relevance of the concept of capacity for the management of a tourist destination: theory and application to tourism management in Venice. Rivista Italiana di Economia Demografia e Statistica, LXVI (2), 142-156.

Mbaiwa, J. E. (2005). Enclave tourism and its socio-economic impacts in the Okavango Delta, Botswana. Tourism Management, 26, 157-172.

Mearns, K. (2012). Community-based tourism and peace parks benefit local communities through conservation in Southern Africa. Acta Academica, 44(2): 70-87.

Moral Moral, M., Fernández Alles, M. T. \& Sánchez Franco, M. J. (2018). Attitudes of rural accommodation managers towards the development of sustainable tourism. Cuadernos de Turismo, 41: 707-711.

Mtapuri, O. \& Giampiccoli, A. (2020). Toward a Model of Just Tourism: A Proposal. Social Sciences, 9(34): 1-19.

Nel, E. \& Binns, T. (2002). Place marketing, tourism promotion, and community-based local economic development in post-apartheid South Africa. The Case of Still BayThe "Bay of Sleeping Beauty". Urban Affairs Review, 38(2), 184-208.

Nel, E. (2001). Local Economic Development: A Review and Assessment of its Current Status in South Africa. Urban Studies, 38(7), 1003-1024.

Ninaroon, P., Songkhla, R. N. \& Pruksaarporn, S. (2020). Conceptual framework for the antecedent and consequent of happiness in community-based tourism enterprise. The 2020 International Academic Multidisciplines Research Conference in Switzerland, 87-93. 
OECD, (2020). OECD TOURISM TRENDS AND POLICIES 2020. Paris: OECD.

Okazaki, E. (2008) A Community-Based Tourism Model: Its Conception and Use, Journal of Sustainable Tourism, 16:5, 511-529.

Pasko, G. (2016). Carrying Capacity Assessment - An Essential Tool for Sustainable Tourism Development in Coastal Areas of Albania. European Journal of Economics and Business Studies, 2(1): 164-171.

Prasiasa, D.P.O., Astawa, I.N.D., Widari, D.A.D.S. \& Udiyana I.B.G., (2020). Analysis of Community Based Tourism Implementation for Sustainability of Tourism Village in Bali Province. Journal of Tallent Development and Excellence. 12 (1), 152-163.

Pratt, S., Suntikul, W., \& Dorji, U. (2018). Economic sustainability? Examining the linkages and leakages between agriculture and hotels in Bhutan. International Journal of Tourism Research, 20(5), 626-636.

Randle, M., Kemperman, A. \& Dolnicar, S. (2019). Making cause-related corporate social responsibility (CSR) count in holiday accommodation choice. Tourism Management, 75: 66-77.

Rodríguez-Pose, A. \& Tijmstra, S. (2010). On the emergence and significance of local economic development strategies. CAF Working Papers, $N^{\circ}$ 2009/07. Caracas; CAF.

Saarinen, J. (2006). Traditions of sustainability in tourism studies. Annals of Tourism Research, 33(4): 1121-1140.

Saayman, M. \& Giampiccoli, A. (2016). Community-based and pro-poor tourism: Initial assessment of their relation to community development. European Journal of Tourism Research, 12:145-190.

Sabokkhiz, M., Sabokkhiz, F., Shayesteh, K., Malaz, J. \& Shieh, E. (2016). Sustainable Tourism Management by Using Recreational Carrying Capacity Concept (Case: Mesr Desert in Iran). Review of European Studies, 8(4): 105-112.

Sánchez-Cañizares, S. M., Castillo-Canalejo, A. M. \& Cabeza-Ramírez, L. J. (2018). Sustainable Tourism in Sensitive Areas: Bibliometric Characterisation and Content Analysis of Specialised Literature. Sustainability, 10, 1525, 1-19.

Scheyvens, R. (2007). Exploring the Tourism-Poverty Nexus. In M. Hall (Ed.), Pro-poor tourism: who benefits? Perspective on tourism and poverty reduction (pp.121-144). Clevedon: Channel View Publications.

Smith, R. A. \& Ong, J. L. T. (2015) Corporate Social Responsibility and the Operationalization Challenge for Global Tourism Organizations, Asia Pacific Journal of Tourism Research, 20:5, 487-499.

Spinrad, B. K., Seward, S. B. \& Bélisle, F. J. (1982). Introduction. In Seward, S. B. \& Spinrad, B. K. (Eds.), Tourism in the Caribbean: The Economic Impact, pp. 7-22. Ottawa: International Development Research Centre.

Strydom, A. J., Mangope, D. \& Henama, U. S. (2017). Economic sustainability guidelines for a Community-Based Tourism Project: The Case of Thabo Mofutsanyane, Free State Province. African Journal of Hospitality, Tourism and Leisure, 6(3), 1-17. 
Tasci, A, Semrad, K. \& Yilmaz, S. (2013). Community based tourism finding the equilibrium in COMCEC context: Setting the Pathway for the Future. Ankara: COMCEC Coordination Office.

Terzioglu, M. \& Gokovali, U. (2016). Economic linkages and leakages in the hotel industry: The first empirical evidence from Turkey. Tourism Economics, 22(4) 715728.

Thomas, A., Moore, A. \& Edwards, M. (2018). Feeding island dreams: exploring the relationship between food security and agritourism in the Caribbean. Island Studies Journal, 13(2), 145-162.

Tien, N. H., Anh, D. B. H., \& Ngoc, N. M. (2020). Corporate financial performance due to sustainable development in Vietnam. Corporate Social Responsibility and Environmental Management, 27(2), 694-705.

Trong Tuan, L. (2011). Corporate Social Responsibility and Sustainable Tourism. Business and Economic Research, 1(1- E4):1-9.

UNCSD NGO steering committee, (1999). Tourism and sustainable development. Sustainable tourism: a non-governmental organization perspective. Background paper \# 4. New York: United Nation.

UNWTO (2002). Tourism and Poverty Alleviation. Madrid: UNWTO.

Wijaya, P. Y., Hartati, P. S. \& Sumadi, N. K. (2020). The Readiness of Community Based Tourism Village Development (Case Study at Bongkasa Pertiwi Tourism Village, Bali Province, Indonesia). European Journal of Business and Management Research, 5(3), 1-5.

Wiranatha, A. S., Antara, M. \& Suryawardani, I. G. A. O. (2017). Impact of Tourism Leakage on the Growth of Economic sectors, Employment and Income Distribution in Bali, Indonesia. International Journal of Economic Research, 14(8), 1-17.

WTO, (1983). Risks of Saturation of Tourist Carrying Capacity Overload in Holiday Destinations. Madrid: WTO.

Yim, S., Bae, Y. H., Lim, H., \& Kwon, J. (2019). The role of marketing capability in linking CSR to corporate financial performance: When CSR gives positive signals to stakeholders. European Journal of Marketing, 53(7), 1333-1354. 